\title{
Mergers and accounting performance: Some evidence from Greece during the economic crisis
}

\author{
Michail Pazarskis ${ }^{\mathrm{a}, 1}$, George Drogalas ${ }^{\mathrm{b}}$ and Andreas Koutoupis ${ }^{\mathrm{c}}$ \\ ${ }^{a}$ T.E.I. of Central Macedonia, Greece \\ ${ }^{\mathrm{b}}$ University of Macedonia, Greece \\ ${ }^{\mathrm{c}}$ T.E.I. of Thessaly, Greece
}

\begin{abstract}
The study examines the impact of mergers on the accounting performance of merger-involved firms in Greece. The study analyses four basic profitability ratios from financial statements of a sample of sixty Greek listed firms at the Athens Exchange that executed as acquirers' one merger in the period a tenyear-period (2005-2014). In order to measure firms' accounting performance, comparisons of pre- and post-merger firm profitability are examined for one year before and after the merger events (with data analysis from 2004 to 2015). The results revealed that mergers have had a negative impact on profitability and, in general, on accounting performance of the merger-involved firms. Furthermore, the study investigates the impact of the economic crisis on the success of mergers in Greece. There is evidence there is also a negative effect on accounting performance after mergers during the period of the economic crisis in Greece.
\end{abstract}

Keywords: mergers, accounting performance, financial ratios, economic crisis

JEL codes: G34, M40

\section{Introduction}

The strategy literature commonly argues that mergers and acquisitions (M\&As) are one of the mechanisms by which firms gain access to new resources in business sectors and, via resource redeployment, increase revenues and reduce cost. The main hypothesis in successful M\&As activities is that potential economic benefits arising from them are changes that increase business performance that would not have been made without a change in firm's control. However, many researchers and business practitioners regard with scepticism this hypothesis, despite the fact

1 Corresponding author: Department of Accounting and Finance, Technological Educational Institute (T.E.I.) of Central Macedonia, End of Magnisias Street, Serres, Greece, GR-621 00, tel.: (+30) 2321049 (306), e-mail address: pazarskis@ gmail.com 
that many others are confident and enthusiastic (Ramaswamy \& Waegelein, 2003; Tao et al., 2017). A characteristic declaration of this contradiction is a remark by Dennis Mueller (1989) that, even it has been stated almost four decades ago, it is still holds:

"No topic in industrial organization generates as much disagreement and controversy as mergers. Why do they occur? What are their economic and noneconomic consequences? What ought government policies toward mergers be? Each question has been given a variety of answers, some diametrically opposed to one another." (Mueller, 1989, p. 1)

The last decades, most of the research on mergers has focused on the financial performance with analysis of stock returns around announcement dates, presenting a positive or negative aspect of mergers, but without always testing the ex-post accounting performance (Caves, 1989). However, the stock price performance (financial performance) studies are not always able to determine whether mergers create real gains or losses and to provide direct evidence on the sources of any merger-related result, as it is difficult to distinguish between stock-market inefficiencies and improvements in performance resulting from the merger (Sharma \& Ho, 2002). The examined increases or decreases in equity values are typically attributed to some unmeasured source of real economic factors (such as synergy) or a general and not well established idea (as management past decisions) (Healy et al., 1992; Pazarskis et al., 2017). As this kind of research could partially not be correct, as many other factors influence stock prices, the examination of accounting performance with the use of ratios from financial statements (and especially, accounting ratios which test directly firm's profitability as ROE and ROA) is a better and safer path to examine merger transactions (Healy et al., 1992; Chatterjee \& Meeks, 1996; Sharma \& Ho, 2002; Marfo Oduro \& Kwaku Agyei, 2013; Rodionov \& Mikhalchuk, 2016; Rao-Nicholson et al., 2016).

Furthermore, it is obvious that after the outbreak of the U.S. crisis in mid-2007 and the debt crisis in Greece in the end of 2009, the reduction of profitability dominated almost in every Greek business section. In 2009, the Greek government resorted to the 'support mechanism', a mechanism which was set up by the International Monetary Fund, the European Union and the European Central Bank. During the following period, the Greek companies of every size and industry were faced with a multitude of complex financial problems.

The bibliography shows that before every economic crisis beginning many firms could have the opportunities and more easily to access a stock market as its members. However, as the situation is getting worse, as was in Greece in the period of economic crisis, it was almost observable and everyone noticed that this crisis was not temporary; also, it becomes obviously difficult for firms, listed or not, to find new paths on how to deal with their business risk and their profitability (Pantelidis et al., 2014). Now businesses have to use all possible means to face new challenges in the middle of a crisis. On the other side, but within an optimistic approach, this crisis also created new opportunities that would help them to survive and thrive in this changing world. In their effort to survive, some of the companies consider the option of merger as a potential in this changing landscape. However, it is quite interesting from a research point to examine this economic activity and performance of firms during a period of long economic crisis in a small open economy (as it is Greece) and its effects on the merger decision.

Thus, the purpose of the study is to provide an answer to the above research dilemmas with the examination of the accounting performance of merger-involved firms in Greece and provide analytically further evidence for the Greek market, 
given the limited number of performance studies on mergers with accounting ratio analysis. Analytically, the aim of the study is to attempt to reveal new insights in mergers transactions during the period of an economic crisis in a small open economy, as it is happening now in Greece, and simultaneously, to provide some basic points on the legal framework of mergers in Greece for a potential investor. To the best of our knowledge, this is the first study that try investigates the impact of the economic crisis on the success of the merger activity in Greece with the examination of accounting measures of earnings and profitability in relation to total assets, equity and sales.

In order to examine the performance of Greek firms after merger activities, this study proceeds to an analysis of the post-merger performance of a sample of sixty firms, listed at the Athens Exchange in Greece that executed one merger in a tenyear-period, using four basic profitability ratios, and attempts to investigate the merger effects on their performance. The results revealed that mergers have a negative impact on profitability and, in general, on accounting performance of the merger-involved firms. Also, there is evidence there is a negative effect on accounting performance after mergers during the period of the economic crisis in Greece

The structure of the paper is as follows: section 2 describes the legal framework on mergers in Greece and the next analyse related past researches on accounting performance with ratios and financial statements' analysis, the following section describes the research design of the study (sample and data, selection of variablesfinancial ratios, research methodology and hypotheses). Section 4 presents and analyses the results. Finally, the last section concludes the paper.

\section{Legal framework on mergers of S.A. in Greece}

Corporate restructuring or business transformation is strictly described by the article 1 of the Greek law 2166/1993 and may be carried out by the merger of enterprises. Business merger is generally considered to be the act of an integrated union of two or more enterprises, which takes place at every operational level. Well and comprehensively, it was attributed to the term of the "economic integration of two or more businesses under unified will" (Perakis, 2001). As any case of corporate restructuring or business transformation, the merger is characterized by the continuation of the productive and, more generally, business of the enterprise in the form of an economic operator, which has separate legal autonomy.

The implementation of the merger act requires various legal acts and acts such as decisions of general meetings of merging companies, drafting a merger agreement, valuation of the assets of the parties involved, amendment of company statutes, publication of approved decisions and merger agreement, etc. The above acts are differentiated directly according to the transfer of assets through "universal" or "special" succession.

In the case of the transfer of the assets of the merging companies through their "universal" succession to the newly created company, we have the merger of two or more legal persons resulting in the creation of a single legal entity as a result of the association of the former merged companies under the rules of company law. This case is called as a "genuine" or a "literally merged" business. 
In contrary at the case of the "special" succession, the merger is accomplished with a different implementation of the merger. Thus, actions are taken to achieve results corresponding to the merger either by transforming a company from one legal form to another (e.g. from a limited liability company to a Joint-stock company - S.A. company) and then merging it with another limited liability company either by resolution and liquidation of an existing public limited liability company and then the contribution of the property resulting from this process to an existing public limited company or in the form of a business branch contribution in accordance with the article 4 of the Greek law 2166/1993. These indicative acts help to call a merger operation with their use as an abusive merger with a "special" succession (Perakis, 2001; Pazarskis et al., 2010).

Finally, regarding the way in which a merger between joint-stock companies (S.A.) companies, in accordance with the article 68 of the Greek law 2190/1920 (as amended by the article 9 of the presidential decree 498/1987, which is an adaptation of Greek law to articles 2, 3 (paragraph 1) and 4 of the Third EU Directive), it is stipulated that the "a merger of S.A. companies takes place either by absorption or by the formation of a new company":

(a) Merger by absorption is an act by which one or more S.A. companies (absorbed), which are dissolved without going into liquidation, transfer to the other existing S.A. company (absorbing) all their assets (assets and liabilities) against return to shareholders of the shares issued by the acquiring company and, where appropriate, payment of a cash amount to clear the shares to which they are entitled. This amount may not exceed $10 \%$ of the nominal value of the shares attributable to the shareholders of the acquiree and the cumulative value of the shares in the net asset value of these companies.

(b) Merger by the formation of a new company is the act whereby two or more S.A. companies, which are dissolved without going into liquidation, transfer to their S.A. company all their assets (assets and liabilities) to their shareholders, shares issued by the new company and, where appropriate, a cash amount in cash to offset the shares to which they are entitled. That amount may not exceed $10 \%$ of the nominal value of the shares attributable to the shareholders of the companies being dissolved and the cumulative value of those shares being the net asset value of the assets of these companies.

It follows from the above that the merger between S.A. companies can be effected either by absorption or by the formation of a new company and the difference between these two modes is that they result in the creation of a new legal entity which in the first case originated from the absorption of an existing of the company, while in the second case it results from the merging of the existing companies. Also, the conceptual elements found in a merger transaction are:

(i) participation and partnership in such direction of two or more existing public limited companies,

(ii) recording their partnership in a merger transaction, either by absorption or by the formation of a new company,

(iii) dissolution of existing companies without liquidation, carried out prior to the merger,

(iv) the transfer of all the assets of existing S.A. companies to the new company, which is either the acquiring company or the new company,

(v) redeem shares in the merging companies, issued as a result of the merger, with any additional payment of a sum of money (Perakis, 2001). 
Furthermore, in relation to cross-border mergers of companies of different Member States in the European Union-EU, Law 2578/1998 (as amended by law 3517/2006) implemented the EU Mergers Tax Directive into Greek law (relative Directive 90/434, as amended by Directive 2005/19, respectively) and applies to corporate restructuring (mergers, demergers, contribution of assets, etc.). Also, Law $3777 / 2009$ enhances the process of cross-border mergers of companies and was implemented, in accordance with the provisions of EU Directive 2005/56, as EU aims for the further expansion of the EU companies within the EU market.

Regarding the general legal framework of the taxation for the merger decision, it is described by the Law 4172/2013 (Greek Income Tax Code-GITC), according to the EU Merger Directive 2009/113. This EU Directive provides a common system for the taxation of company restructuring (as mentioned above) concerning companies in different EU Member States and provides the opportunities for some merger transactions with capital gains that are not subject to tax from mergers. The provisions of articles 52 to 56 of the Law shall apply to corporate restructuring made from 1 January 2014 onwards.

Also, according to the process and the nature of the negotiations, as well as the agreement of companies' management, if it is pro- or contra-oriented to the M\&As action (this is partially regulated in Greece by the Law 3461/2006 for the process of a public offer), M\&As activities are distinguished as: (a) friendly M\&As, where the acquirer and the acquired company achieve a common agreement on this specific action, there is a common consensus, and no official reaction on the completion of the process and (b) hostile M\&As or takeovers, where the target company express its disagreement to the M\&A action, and attempt to defend itself through some precise actions from the eventual acquirer company.

Last, starting from 2005 all publicly listed firms in the European Union-EU member states were required to prepare their financial statements according to the International Accounting Standards-IAS (see, EU Regulation 1606/2002 for the mandatory adoption of IAS from 2005 onwards). Compliance with IAS is compulsory for the publicly listed firms in Greece since January 2005, while other firms that are not obliged to apply IAS still use Greek GAAP. The relevant IAS is the IFRS 3 - Business Combinations, which is designed to determine the accounting when an acquirer obtains control of a business (see, M\&As). It sets out the principles on the recognition and measurement of acquired assets and liabilities, and the determination of goodwill with the use of the "acquisition method", which requires assets acquired and liabilities assumed to be measured at their fair values at the acquisition date (Pazarskis et al., 2017).

\section{Literature review}

Diachronically, several studies on M\&As that employed accounting ratios supported an improvement in the corporate performance after the M\&As action (Cosh et al., 1980; Rao-Nicholson et al., 2016), while others claimed that there was a deterioration in the post-merger firm performance (Meeks, 1977; Salter \& Weinhold, 1979; Mueller, 1980; Kusewitt, 1985; Ravenscraft \& Scherer, 1987; Dickerson et al., 1997; Sharma \& Ho, 2002; Marfo Oduro \& Kwaku Agyei, 2013), and some others concluded a "zero" result or ambiguous results from the M\&As action (Kumar, 1984; Healy et al., 1992; Chatterjee \& Meeks, 1996; Ghosh, 2001; Bhabra \& Huang, 2013; Rodionov \& Mikhalchuk, 2016). The main characteristics of studies that examined the changes with ratios in post-merger performance of acquiring firms are the different choices of measures which vary form study to 
study, while always exists the susceptibility of accounting information under the possible different accounting policies (Bhabra \& Huang, 2013).

One initial research that utilizes the company's financial statements to compute ROA and sales margin carried out by Rao-Nicholson et al. (2016), which examine the post-M\&A performance in ASEAN countries using data from 2001 to 2012. They compare ROA and sales margin for three years following an M\&A and their results suggest that M\&As completed during the financial crisis are more profitable than those implemented before and/or after the crisis. Rao-Nicholson et al. (2016) argue that this is mainly due to the synergies created between the firms' resources during the crisis which augur well for firms' economic performance.

For the Russian market, Rodionov \& Mikhalchuk (2016) develop an econometric model based on financial statements suitable for valuation of synergies in Russian domestic M\&A deals. Rodionov \& Mikhalchuk (2016) test empirical hypotheses about factors of synergy creation in 2006-2014 and, examining results for synergies of companies that participated in the deal, found a decline of post-merger performance in crisis periods.

As merger transactions attract the interest of researchers worldwide, Sharma \& Ho (2002) investigate the impact of acquisitions on the post-M\&As performance for the Australian market. From a sample of 36 acquisitions of Australian firms occurring (between 1986 to 1991 inclusive), they examine four accrual performance measures (ROE, ROA, Profit margin and Earnings per share-EPS). Sharma \& Ho (2002) argue that corporate acquisitions do not lead to significant improvements in post-acquisition performance.

For the UK market, Dickerson et al. (1997) studied a large sample of British companies (613 cases) that made M\&As during the period 1948-1977. In their investigation, which is considered to be large both for the size of the sample of companies and for the period considered, they have come to the conclusion that the ROA of the acquiring undertakings during the first five years after the transaction were lower by $2 \%$ other UK companies not involved in M\&As activities. Another study for the UK market of Chatterjee \& Meeks (1996) examined 144 M\&As activities for the period 1977 to 1990 with a sample of British businesses only. With this survey, they concluded that there was no change in business profitability for the period 1977-1985. They also argued that this was not for the case of the period 1985-1990 (the remainder of their investigation), where there was a significant improvement in the profitability of the businesses involved in the range of $13 \%$ to $22 \%$, which was mainly attributed from them to changes in tax policy in the UK.

For the US market, Healy et al. (1992) investigated the fifty largest mergers in the United States for the period 1979-1984. Although on the one hand their research found that there was a significant improvement in the overall liquidity ratio, they did not find any positive change or increase in the net margin or net profit ratio of the enterprises involved. In addition to this improvement in the overall liquidity index recorded on average for their sample, this was essentially derived from threequarters of the sample of companies that they examined, while the rest of a quarter from their operations had deteriorated their overall liquidity. Also, Healy et al. (1997) report in another article, on the same sample and for the same period of time as above, that they found increased operating cash flows as a result of the combined activities of the merging companies but in no case their profit was greater than the price was paid for the M\&As concerned. Based on this, they 
argued that any M\&As activities were essentially of zero Net Present Value (NPV) investment activities.

For a developing economy, Marfo Oduro \& Kwaku Agyei (2013) argued that improved profitability is among the key benefits sought from mergers and acquisitions. Their study attempts to seek for the effects M\&As on the performance of firms in the Ghanaian Stock Market from 1999 to 2010. The study was accounting based using ROE and they performed univariate analysis with t-testing. The univariate analysis revealed dwindling profitability after the merger for all the firms with the t-test showing significant difference in profitability before and after merger.

Regarding the Greek market, there are few studies that evaluate performance of firms after M\&As using accounting ratios. As above, some Greek studies supported an improvement in the corporate performance after the M\&As action (Mylonidis \& Kelnikola, 2005; Agorastos et al., 2011), while others claimed that there was a deterioration in the post-merger firm performance (Alexandrakis et al., 2012; Pantelidis et al., 2014), and some others concluded a "zero" result or ambiguous results from the M\&As action (Pazarskis et al., 2017).

\section{Research design}

\subsection{Sample and data}

The final sample consists of sixty firms, listed in the Athens Exchange that executed one merger action as acquirers in Greece during the period from 2005 to 2014 (see Appendix). The merger events of the Greek listed firms have been tracked from their announcements on the web site of the Athens Exchange in Greece and with the examination of the annual reports of the Athens Exchange. The accounting data of the study (accounting measures for the ratios' computation) are extracted from the financial statements of the merger-involved firms, which were received from the published data on the Athens Exchange's website.

The study proceeds to an analysis only of listed firms as their financial statements are published and it is easy to find them and evaluate from them the firms' performance. Also, the sample of sixty merger events is very satisfying and very encouraging, comparable to prior studies conducted in significantly larger markets such as US and UK or the Australian market, with the same or fewer sample firms, as: Healy et al., 1992: $n=50$, Cornett \& Tehranian, 1992: $n=30$, Clark \& Ofek, 1994: $n=38$, Manson et al., 1995: $n=38$, Sharma \& Ho, 2002: $n=36$.

\subsection{Selection of variables (ratios)}

The accounting performance of a firm is evaluated with its performance at four profitability ratios. For the purpose of this study, the ratios chosen (V1-V4) for the analysis and evaluation of the above sample are in accordance with the methodologies followed at several previous studies (Sharma \& Ho, 2002; Mylonidis \& Kelnikola, 2005; Agorastos et al., 2011; Alexandrakis et al., 2012; Marfo Oduro \& Kwaku Agyei, 2013; Pantelidis et al., 2014; Rao-Nicholson et al., 2016). The four ratios, which employ the accounting measures of earnings and profitability, in relation to total assets, equity and sales, are tabulated in the next table. 
Table 1. Classification of financial ratios

\begin{tabular}{cll}
\hline Code & Variable Name & Ratio analysis \\
\hline V1 & EBITDA Margin & EBITDA/sales \\
V2 & EBIT Margin & EBIT/sales \\
V3 & ROA & Earnings/total assets \\
V4 & ROE & Earnings/equity \\
\hline
\end{tabular}

\subsection{Research methodology and hypotheses}

The study employs four ratios as modified measures of accounting performance, which are relations of earnings and profitability to total assets, equity and sales. The fundamental research question that is investigated by examining the above mentioned ratios is the following: "Is accounting performance in the post-merger period greater than it is in the pre-merger period, and is there any impact of the economic crisis?".

\subsubsection{Evaluation of post-merger firms' performance}

The M\&As action of each company from the sample is considered as an investment that is evaluated by the NPV criterion (if NPV $\geq 0$, the investment is accepted). Based on this viewpoint, the study proceeds to its analysis and regards the impact of an M\&As action similar to the impact of any other positive NPV investment of the firm to its ratios over a specific period of time (Healy et al., 1992; 1997; Alexandrakis et al., 2012; Pantelidis et al., 2014). Thus, in this study the following first hypothesis has been formulated:

$H_{1}$ : Mergers are not expected to have a relative change on the post-merger performance of the acquiring firms.

The selected financial ratios for each company of the sample over a one-year period before (year $t-1$ ) or after (year $t+1$ ) the merger event are calculated, and the mean from the sum of each ratio for the years $\mathrm{t}-1$ is compared with the equivalent mean from the years $t+1$, respectively. In this study, the mean from the sum of each ratio is computed than the median, as this could lead to more accurate research results. This argument is consistent with many other researchers diachronically (Cornett \& Tehnarian, 1992; Sharma \& Ho, 2002; Pantelidis et al., 2014). Also, the study does not include in the comparisons the year of merger event $(t=0)$, because this usually includes a number of events which influence firm accounting performance in this period (as one-time merger transaction costs, necessary for the deal, etc.) (Healy et al., 1992; Pazarskis et al., 2017). Last, to test this hypothesis two independent sample mean t-tests for unequal variances are applied.

\subsubsection{Evaluation of the impact of economic crisis}

According to Rao-Nicholson et al. (2016) the M\&As in ASEAN countries completed during the financial crisis are more profitable than those implemented before and/or after the crisis. For the Greek market, Pantelidis et al. (2014) argued M\&As before the beginning of the economic crisis (examined years 2008-2009) had a negative impact on the post-merger performance (especially, on profitability ratios) of merger-involved firms. Rodionov \& Mikhalchuk (2016) based on financial statements found for the Russian market also a decline of post-merger 
performance in crisis periods. In order to reveal the impact of the economic crisis in Greece, we examine the sample firms in two separate groups: the firms with mergers in the Pre-crisis period (years 2005-2008) and the firms with mergers in the period of Greek crisis (2009-2014). So, the second hypothesis that has been formulated is the following:

$\mathrm{H}_{2}$ : Mergers are not expected to have a relative change on the post-merger performance of the acquiring firms before or in the period of Greek economic crisis.

More analytically, in order to examine the impact of the economic crisis in Greece at the post-merger accounting performance with the examined four ratios, regarding to the above referred argument, the study analyses the data of the research sample firms and categorize them in two groups from this respect:

- PRE-Crisis: 50\% (30 firms) has done their mergers' transaction in the period before the economic crisis (2005-2008) and

- IN-Crisis: $50 \%$ (30 firms) has done their deal in the period of the economic crisis in Greece (2009-2014).

Next, we apply a modified methodology of Ramaswamy \& Waegelein (2003) and Francis \& Martin (2010), where change in acquirer's accounting performance is measured as the change in a ratio (e.g. ROA) from before to after the merger (thus: $\Delta \mathrm{ROA}$ ). More specifically, $\Delta V X$ is equal to the average of a ratio from year $\mathrm{t}+1$ $(\mathrm{t}-1)$ for the sample firms, while $\mathrm{t}=0$ denotes the merger year and the ratio change is computed as below:

$$
\Delta V X_{i}=\bar{X}_{2 i}-\bar{X}_{1 i}
$$

where, $\Delta V X$ calculate the differences between the means of post- and pre-merger ratios, $i$ refers to the examined ratios $\{\mathrm{V} 01, \ldots, \mathrm{V} 4\}$ of a sample firm, while $\bar{X}_{1}$ presents the mean of pre-merger examined ratios and $\bar{X}_{2}$ is the mean of postmerger examined ratios.

For these data (see, $\Delta V X_{i}$ ), after the rejection of the null hypothesis that the data sample has the normal distribution, a non-parametric test is applied, as nonparametric tests imply that there is no assumption of a specific distribution for the data population: the Kruskall-Wallis test. The Kruskall-Wallis test is a nonparametric test, alternative to the one-way ANOVA test, which does not require the data to be normal, but instead uses the rank of the data values rather than the actual data values for the analysis (Pantelidis et al., 2014; Pazarskis et al., 2017).

\section{Results}

\subsection{Results for post-merger firms' performance}

As the inferences of the analysis in Table 2 showed that two of the four examined profitability ratios are statistically significant, this could reveal a different profitability in the post-merger period than this before merger. In particular, the averages of these financial ratios, extracted from firms' financial statements, were not outperformed after the merger event than in the pre-merger period. The problem of corporations' efficiency, regarding the capacity of the profits before taxes (EBIT and EBITDA) to sales seems to be a problem during the post-merger period. The ratios V1 and V2 that measures the EBIT and EBITDA margin are 
statistically significant ( $p<0.1$ and $p<0.05$, respectively) and is associated with the likelihood of decreased earnings before interest and taxes (and depreciation and amortization) in the financial statements. Thus, the study argues that mergers had a negative impact on performance and profitability of merger-involved firms.

These results are consistent with the results of some others studies that found a decline of the profitability ratios in the post-merger period: Meeks (1977), Salter \& Weinhold (1979), Mueller (1980), Kusewitt (1985), Neely \& Rochester (1987), Ravenscraft \& Scherer (1987), Dickerson et al. (1997), Sharma \& Ho (2002), Alexandrakis et al. (2012), Pantelidis et al. (2014). Also, these results are not consistent with the results of some other past studies, which claimed that there is no relative change of the performance at any examined profitability ratios due to M\&As activities: Kumar (1984), Healy et al. (1992), Chatterjee \& Meeks (1996), Ghosh (2001), Mylonidis \& Kelnikola (2005), Agorastos et al. (2011). Furthermore, our results for the Greek market, since there is no significant profitability improvement, do not support the hypotheses of market power (Lubatkin, 1983; 1987). According to this approach, market power that gained by the acquirer after the merger or the acquisition should increase the new firm's profit margins and therefore, its profitability. Last, the results of this study revealed that as mergers had a negative impact on performance of merger-involved firms, they were finally investment actions of negative value for the sample firms, even one year after the merger transactions, and they do not lead to enhanced performance (Healy et al., 1992; 1997; Alexandrakis et al., 2012; Pantelidis et al., 2014).

Table 2. Results of sample firms for a ten-year-period (2005-2014)

\begin{tabular}{cccccc}
\hline \multirow{2}{*}{ Code } & \multicolumn{2}{c}{ Mean } & t-value & p-value & 95\% CI \\
\cline { 2 - 3 } & pre-merger & post-merger & & & \\
\hline V1 & 12.1 & 6.5 & -2.00 & $0.048^{* *}$ & $(-11.05 ;-0.06)$ \\
V2 & 7.1 & 0.7 & -2.41 & $0.018^{* *}$ & $(-11.70 ;-1.13)$ \\
V3 & -0.3 & -29 & -1.41 & 0.163 & $(-69.6 ; 12.0)$ \\
V4 & -5.1 & -3.3 & 0.26 & 0.798 & $(-12.17 ; 15.77)$ \\
\hline
\end{tabular}

Note: $* * *, * *, *$ indicate that the mean change is significantly different from zero at the $0.01,0.05$, and 0.10 probability level, respectively, as measured by two independent sample mean t-tests. More analytically, the P-value interpretation levels for the above referred three cases are described below: $\mathrm{p}<0.01$ strong evidence against Ho (see, $* * *) ; 0.01 \leq \mathrm{p}<0.05$ moderate evidence against $\mathrm{Ho}$ (see, $\left.{ }^{* *}\right) ; 0.05 \leq \mathrm{p}<0.10$ little evidence against Ho (see, ${ }^{*}$ ); $0.10 \leq \mathrm{p}$ no real evidence against Ho

For further analysis, with this set of four ratios (variables from V1 to V4) that examined the sample firms with mergers during the period 2005-2014 (the whole research period), the study is subtracting the research period into four sub-samples: (a) years 2005-2006: 12 firms; years 2007-2008: 18 firms; years 2009-2010: 14 firms; years 2011-2014:16 firms. We test again the first hypothesis by examining now two periods in the pre-crisis and two during the economic crisis period of the whole examined period with two independent sample mean t-tests for unequal variances. The results in table 3 revealed that three of all the examined profitability ratios had change significantly due to the merger events, but only in the period before and shortly after the outbreak of the economic crisis. More specifically, in the sub-period 2007-2008: (i) the variables V2 and V3 are statistically significant $(p<0.1$ and $p<0.01$, respectively) and imply for a deterioration of EBIT Margin and 
ROA in the post-merger period and (ii) the variables V1 and V2 are statistically significant $(p<0.01$ and $p<0.01$, respectively) and the first implies for an improvement of EBITDA Margin, while the second for a deterioration of EBIT Margin, both in the post-merger period. All-in-all, the above stated proposition of the hypothesis $\mathrm{H}_{1}$ is rejected.

Table 3. Results of sample firms of four sub-samples in a ten-year-period

\begin{tabular}{ccccccccc}
\hline & \multicolumn{7}{c}{ Mean } \\
\cline { 2 - 8 } Code & $\mathbf{2 0 0 5 - 2 0 0 6}$ & \multicolumn{2}{c}{$\mathbf{2 0 0 7 - 2 0 0 8}$} & $\mathbf{2 0 0 9 - 2 0 1 0}$ & $\mathbf{2 0 1 1 - 2 0 1 4}$ \\
\cline { 2 - 8 } & pre-m. & post-m. & pre-m. & post-m. & pre-m. & post-m. & pre-m. & post-m. \\
\cline { 2 - 8 } V1 & 9,3 & 5,2 & 18,1 & 11,5 & $6,22 * * *$ & $7,26 * * *$ & 9,9 & 7,4 \\
V2 & 3,8 & $-0,1$ & $13,3 *$ & $4,18 *$ & $5,42 * * *$ & $-2,85 * * *$ & 4,3 & 0,4 \\
V3 & $-0,03$ & 0,03 & $4,52 * * *$ & $0,67 * * *$ & 4,4 & -13 & $-9,9$ & -17 \\
V4 & -37 & 6,7 & 7,5 & $-9,6$ & $-0,09 *$ & $-4,45^{*}$ & $-0,17$ & $-2,1$ \\
\hline
\end{tabular}

Note: $* * *$ indicates statistically significant at the 0.01 level; $* *$ indicates statistically significant at the 0.05 level; * indicates statistically significant at the 0.1 level.

\subsection{Results before and during the economic crisis}

In order to test the second hypothesis and reveal the impact of the economic crisis in Greece, we examine the sample firms in two separate groups: 30 firms (50\% of the total sample) with mergers in the Pre-crisis period (years 2005-2008) and 30 firms (50\% of the total sample) with mergers in the period of Greek crisis (20092014). The received results are presented in the next table. The ratio $\Delta \mathrm{V} 3$ that measures the change in ROA ratio from before to after the merger (thus: $\triangle \mathrm{ROA}$ ) is statistically significant $(p<0.1)$ and is associated with the likelihood of decreased earnings in comparison to total assets. Thus, our results revealed that mergers have a partial negative impact on the post-merger profitability and performance of merger-involved firms during the period of the economic crisis in Greece.

Table 4. Kruskal-Wallis test in two periods (2005-2008 \& 2009-2014)

\begin{tabular}{|c|c|c|c|c|}
\hline \multirow[b]{2}{*}{ Code } & \multirow{2}{*}{$\begin{array}{l}\text { Variable name of } \\
\text { examined ratio }\end{array}$} & \multicolumn{2}{|c|}{ Median } & \multirow[b]{2}{*}{ p-value } \\
\hline & & $\begin{array}{l}\text { PRE-Crisis } \\
(2005-2008)\end{array}$ & $\begin{array}{c}\text { IN-Crisis (2009- } \\
\text { 2014) }\end{array}$ & \\
\hline$\Delta \mathrm{V} 1$ & $\triangle$ EBITDA Margin & $-1,639$ & $-2,793$ & 0,717 \\
\hline$\Delta \mathrm{V} 2$ & $\Delta$ EBIT Margin & $-1,200$ & $-1,652$ & 0,923 \\
\hline$\Delta \mathrm{V} 3$ & $\triangle \mathrm{ROA}$ & $-1,920$ & $-10,174$ & $0,060 *$ \\
\hline$\Delta \mathrm{V} 4$ & $\triangle \mathrm{ROE}$ & $-2,187$ & $-3,372$ & 0,535 \\
\hline
\end{tabular}

Note: $* * *$ indicates statistically significant at the 0.01 level; $* *$ indicates statistically significant at the 0.05 level; * indicates statistically significant at the 0.1 level.

For further analysis, with the calculated change from the set of four ratios (variables from $\Delta \mathrm{V} 1$ to $\Delta \mathrm{V} 4$ ) that examined the sample firms with mergers during the period 2005-2014 (the whole research period), the study is subtracting the research period them again into four sub-samples: (a) years 2005-2006: 12 firms; years 2007-2008: 18 firms; years 2009-2010: 14 firms; years 2011-2014:16 firms. Now, we test again the second hypothesis by examining as options two periods in the pre-crisis and two during the economic crisis period of the whole examined 
period with the Kruskall-Wallis test. The results in table 5 revealed that one ( $\Delta \mathrm{V} 4$ : $p<0.01$ ) of four examined profitability ratios had change significantly due to the merger events, but seems to have the lowest values in the period before (sub-period 2007-2008) and shortly after (sub-period 2009-2010) the outbreak of the economic crisis.

These results are consistent with the results of some others studies that found a decline of the profitability ratios at the post-merger period in crisis periods: Pantelidis et al. (2014) argued for the Greek market that mergers (examined years 2008-2009) before the beginning of the economic crisis had a negative impact on profitability ratios of merger-involved firms. For the Russian market, Rodionov \& Mikhalchuk (2016), based on financial statements, found also a decline of postmerger performance in crisis periods. Also, these results are not consistent with the results of some other past studies, which claimed that there is an improvement of the post-merger performance during the financial crisis: According to RaoNicholson et al. (2016) the M\&As in ASEAN countries completed during the financial crisis are more profitable than those implemented before and/or after the crisis. All-in-all, the above stated proposition of the hypothesis $\mathrm{H}_{2}$ is rejected.

Table 5. Kruskal-Wallis test in four periods $(2005-2008 \&$ 2009-2014)

\begin{tabular}{|c|c|c|c|c|c|}
\hline \multirow[b]{2}{*}{ Code } & \multicolumn{4}{|c|}{ Median } & \multirow[b]{2}{*}{ p-value } \\
\hline & $\begin{array}{c}\text { PRE-Crisis } \\
(2005-06)\end{array}$ & $\begin{array}{c}\text { PRE-Crisis } \\
(2007-08)\end{array}$ & $\begin{array}{l}\text { IN-Crisis } \\
(2009-10)\end{array}$ & $\begin{array}{l}\text { IN-Crisis } \\
\text { (2011-14) }\end{array}$ & \\
\hline$\Delta \mathrm{V} 1$ & $-0,8645$ & $-2,1370$ & $-10,0275$ & $-0,2570$ & 0,174 \\
\hline$\Delta \mathrm{V} 2$ & $-0,6850$ & $-1,9190$ & $-8,0035$ & 0,6725 & 0,198 \\
\hline$\Delta \mathrm{V} 3$ & 0,2785 & $-2,7260$ & $-10,064$ & $-10,1735$ & 0,208 \\
\hline$\Delta \mathrm{V} 4$ & 2,7020 & $-6,1315$ & $-5,6645$ & $-0,7955$ & $0,015^{* *}$ \\
\hline
\end{tabular}

Note: *** indicates statistically significant at the 0.01 level; $* *$ indicates statistically significant at the 0.05 level; * indicates statistically significant at the 0.1 level.

\section{Conclusions}

For this study we chose as methodology a set of profitability ratios from financial statements to examine the impact of mergers on the accounting performance of merger-involved firms in Greece. Using four ratios (profitability ratios), the postmerger performance of a sample of sixty Greek companies, listed on the Athens Exchange that executed one merger in the period from 2005 to 2014 as acquirers, is investigated. For the purpose of the study, this set of four profitability ratios is employed, in order to measure firms' accounting performance and to compare preand post-merger performance for one year before and after the merger events.

The results revealed that two out of four examined profitability ratios have changed significantly due to the merger events, even one year after the merger transactions. Thus, mergers have had a negative impact on performance of merger-involved firms. Furthermore, the influence of the economic crisis on mergers in Greece is examined separately. Mergers transactions in the pre-crisis period are compared with these during the period of the economic crisis. Our results argued that mergers where not successful in any case for the examined Greek firms as a business strategy before or during the economic crisis period. 
Last, the research results could be used: a) to accounting research for the examination of the post-merger performance of firms during a period of long economic crisis in a small open economy (as it is Greece) and its effects on the merger decision. Furthermore, alternative examined samples could be analyzed (not only of merger-involved listed firms in the Athens Exchange, but also non-listed) or within different time intervals or firms involved in international merger activities (if there are), b) as a recent empirical result of the merger activity and profitability in Greece during the economic crisis for policy makers, tax and other state authorities or investors for their potential investments.

\section{References}

Agorastos, K., Pazarskis, M. \& Karagiorgos, T. (2011) “An accounting comparison of the post-merger economic performance of Greek acquiring listed firms in domestic vs. international M\&As at South-East Europe", International Journal of Trade and Global Markets, 4: 328-342

Alexandrakis, A., Mantzaris, I. \& Pazarskis, M. (2012) "The Impact of Mergers on Company Performance: Evidence from the Greek Industrial Goods and Services Sector", South European Review of Business Finance and Accounting, 10: 53-68

Bhabra, H. \& Huang, J. (2013) "An empirical investigation of mergers and acquisitions by Chinese listed companies, 1997-2007", Journal of Multinational Financial Management, 23: 186-207

Caves, R. (1989) "Mergers, Takeovers, and Economic Efficiency; Foresight vs. Hindsight", International Journal of Industrial Organization, 7: 151-174

Chatterjee, S. \& Meeks, G. (1996) "The financial effects of takeover: accounting rates of return and accounting regulation”, Journal of Business Finance \& Accounting, 23: 851-868

Clark, K. \& Ofek, E. (1994) "Mergers as a means of restructuring distressed firms: an empirical investigation", Journal of Financial and Qualitative Analysis, 29(4): 541-565

Cornett, M. \& Tehnarian, H. (1992) "Changes in corporate performance associated with bank acquisitions", Journal of Financial Economics, 31: 211-234

Cosh, A., Hughes, A. \& Singh, A. (1980) "The causes and effects of takeovers in the U.K.: An empirical investigation for the late 1960s at the microeconomic level", in D. Mueller, eds., "The Determinants and Effects of Merger: An International Comparison", Gunn \& Horn Publications, Cambridge, U.K.

Dickerson, A., Gibson, H. \& Tsakalotos, E. (1997) "The Impact of Acquisitions on Company Performance: Evidence from a Large Panel of U.K. Firms," Oxford Economic Papers, 49: 344-361

Francis, J.R. \& Martin, X. (2010) "Acquisition profitability and timely loss recognition", Journal of Accounting and Economics, 49: 161-178

Ghosh, A. (2001) "Does operating performance really improve following corporate acquisitions?", Journal of Corporate Finance, 7: 151-178

Healy, P., Palepu, K. \& Ruback, R. (1992) "Does corporate performance improve after mergers?", Journal of Financial Economics, 31: 135-175

Healy, P., Palepu, K. \& Ruback, R. (1997) "Which takeovers are profitable: strategic of financial?", Sloan Management Review, 38: 45-57

Kumar, M. (1984) Growth, Acquisition and Investment, Cambridge University Press, Cambridge, U.K.

Kusewitt, J. (1985) "An explanatory study of strategic acquisition factors relating to performance", Strategic Management Journal, 6: 151-169 
Lubatkin, M. (1983) "Merger and the performance of the acquiring firm", Academic of Management Review, 8: 218-225

Lubatkin, M. (1987) "Merger strategies and stockholder value", Strategic Management Journal, 8: 39-53

Manson, S., Stark, A. \& Thomas, H. (1995) "A Cash Flow Analysis of Operational Gains from Takeovers", Certified Research Report 35, The Chartered Association of Certified Accountants, London, UK.

Marfo Oduro, I. \& Kwaku Agyei, S. (2013) "Mergers \& Acquisition and Firm Performance: Evidence from the Ghana Stock Exchange", Research Journal of Finance and Accounting, 4: 99-107

Meeks, G. (1977) "Disappointing marriage: a study of the gains from merger", University of Cambridge: Occasional Paper 51, Cambridge University Press, Cambridge, U.K.

Mueller, D. (1980) The Determinants and Effects of Merger: An International Comparison, Gunn \& Horn Publications, Cambridge, U.K.

Mueller, D. (1989) "Mergers, causes, effects and policies", International Journal of Industrial Organization, 7: 1-10

Mylonidis, N. \& Kelnikola, I. (2005) "Merging activity in the Greek Banking System: A financial accounting perspective", South Eastern Europe Journal of Economics, 1: 121-144

Neely, W. \& Rochester, D. (1987) "Operating performance and merger benefits: the savings and loans experience", Financial Review, 22: 111-129

Pantelidis, P., Pazarskis, M., Deloudi, K. \& Stamatouros, S. (2014) "Do M\&As of Greek listed firms before the economic crisis improved their current liquidity and profitability?", MIBES Transactions - International Journal, 8: 100-112

Pazarskis, M., Alexandrakis, A. \& Karagiorgos, T. (2010) "Review of the legal framework of M\&As in Greece from accounting-financial perspective and issues of its reform", PRIME - International Journal, 3: 42-57

Pazarskis, M., Drogalas, G. \& Koutoupis, A. (2017) "Mergers, taxation and accounting performance: some evidence from Greece", Journal of Accounting and Taxation, 9: 119-130

Perakis, E. (2001) Corporate restructuring, $2^{\text {nd }}$ edition, Law Library, Athens, Greece

Ramaswamy, K.P. \& Waegelein, J. (2003) "Firm financial performance following mergers", Review of Quantitative Finance and Accounting, 20: 115-126

Rao-Nicholson, R., Salaber, J. \&Cao, T. H. (2016) "Long-term performance of mergers and acquisitions in ASEAN countries", Research in International Business and Finance, 36: 373-387

Ravencraft, D. \& Scherer, F. (1987) Mergers, Sell-Offs and Economic Efficiency, Brookings Institution, Washington, U.S.

Rodionov, I. \& Mikhalchuk, V. (2016) "M\&A Synergies in Domestic M\&A Deals in Russia in 2006-2014", Russian Management Journal, 14: 3-28

Salter, M. \& Weinhold, W. (1979) Diversification Through Acquisition; Strategies for Creating Economic Value, Free Press, New York, U.S.

Sharma, D. \& Ho, J. (2002) "The impact of acquisitions on operating performance: some Australian evidence", Journal of Business Finance \& Accounting, 29: $155-200$

Tao, F., Liu, X., Gao, L. \& Xia, E. (2017) "Do cross-border mergers and acquisitions increase short-term market performance? The case of Chinese firms", International Business Review, 26: 189-202 


\section{Appendix: Greek listed firms with a merger decision in the period 2005-2014}

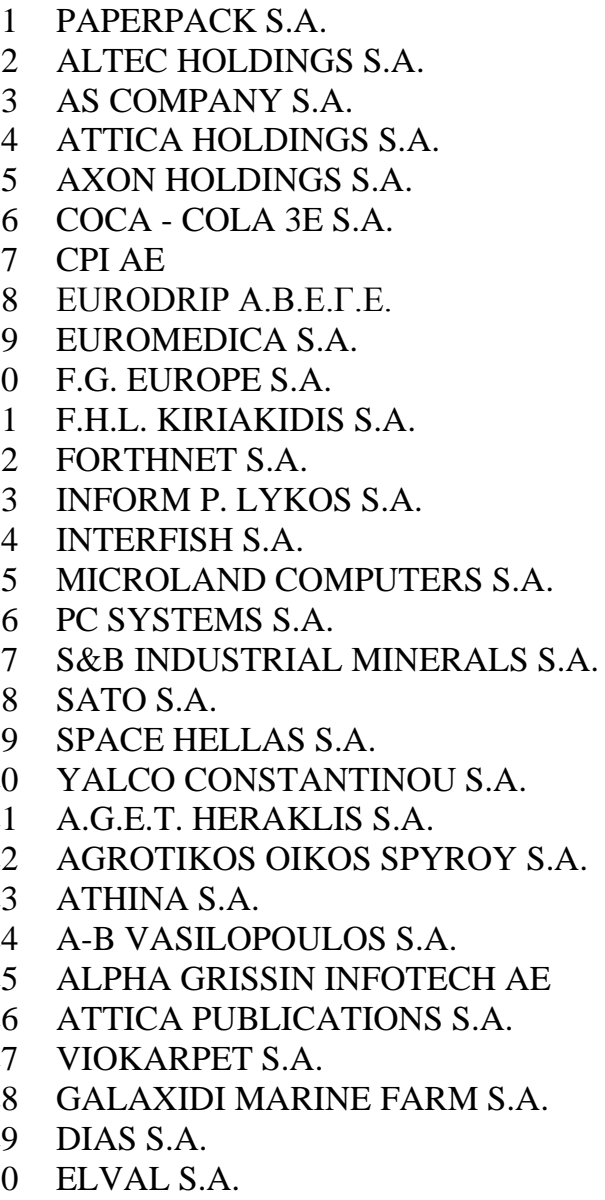

31 ELVE S.A.

32 HELLENIC CABLES S.A.

33 HELLENIC PETROLEUM S.A.

34 HELLENIC EXCHANGES S.A.

35 HELLENIC FISH FARMING S.A.

36 AUDIOVISUAL S.A.

37 NAFTEMPORIKI S.A.

38 IKTINOS HELLAS S.A.

39 INTRAKAT S.A.

40 HIPPOTOUR S.A.

41 SELONDA S.A.

42 NAFPAKTOS TEXTILE INDUSTRY S.

43 KORDELOS BROS S.A.

44 KRE-KA S.A.

45 CRETA FARM S.A.

46 MATHIOS REFRACTORIES S.A.

47 MARAK ILEKTRONIKI S.A.

48 METKA S.A.

49 MIHANIKI S.A.

50 MYTILINAIOS S.A.

51 NIREYS S.A.

52 NIKAS S.A.

53 XILEMPORIA S.A.

54 O.T.E. S.A.

55 P. PETROPOULOS S.A.

56 SFAKIANAKIS S.A.

57 CORINTH PIPEWORKS S.A.

58 YГEIA S.A.

59 HAIDEMENOS S.A.

60 HATZIIOANNOU S.A. 